Maire OJAVEER, V. SARV

\title{
A NOVEL AC VOLTAGE PHASE-CONTROL CIRCUIT WITH REDUCED DISTORTIONS AND SWITCH VOLTAGES
}

\author{
(Presented by I. Opik)
}

A novel AC voltage phase-control circuit emloying an interphase variable-ratio autotransformer for eliminating lower distortion harmonics is presented and analyzed. The autotransformer with a suitable stepped transformation-ratio modulation enables both the proper interphase energy exchange control and matching of supply and switch voltages.

\section{Introduction}

The use of switches in power converters as basic conversion elements gives an inevitable generation of distortion harmonics $\left[{ }^{1,2}\right]$. It is essential to reduce these unwanted harmonics of input and output currents in the converter to an acceptable level. For solving this problem in AC voltage controllers, a corresponding control of interphase energy exchange is efficient $\left[{ }^{3-6}\right]$. The proper interphase energy exchange required for the elimination of lower distortion harmonics can be realized by using an interphase variable-ratio transformer or autotransformer with a suitable stepped transformation-ratio modulation $\left[{ }^{5-11}\right]$. In these circuits control both with lagging and leading currents is possible, but in the latter case fully-controllable switches are needed.

If power transistors with limited rated voltage are used as fully-controllable switches, matching of supply and switch voltages is essential. This problem can be solved by using an interphase transformer with separate windings for the load and switching circuits $\left[{ }^{11}\right]$. In this case; however, the increase of the converter size and weight is inevitable.

In this paper a novel AC voltage phase-control circuit employing an interphase autotransformer both for energy exchange control and for matching of supply and switch voltages, is proposed and analyzed.

\section{General discussion}

In the proposed $\mathrm{AC}$ voltage phase-control circuit of Fig. 1 the interphase autotransformer is connected in series with a symmetrical three-phase load. Tapped windings in delta connection are used in the autotransformer to allow the stepped modulation of the interphase transformation ratios. The positions of taps are chosen so that, in the case of all switches opened, voltages across the switches are shifted by $2 \pi / p$, where $D$ is the number of unidirectional switches in the conversion circuit and the pulse number as well. In practice it is suitable to take $p=12\left[{ }^{12}\right]$.

During the circuit operation at least one switch is on. The sequence of switching on corresponds to that of the voltages across the switches for all switches opened. The appropriate sequence of switching on with 


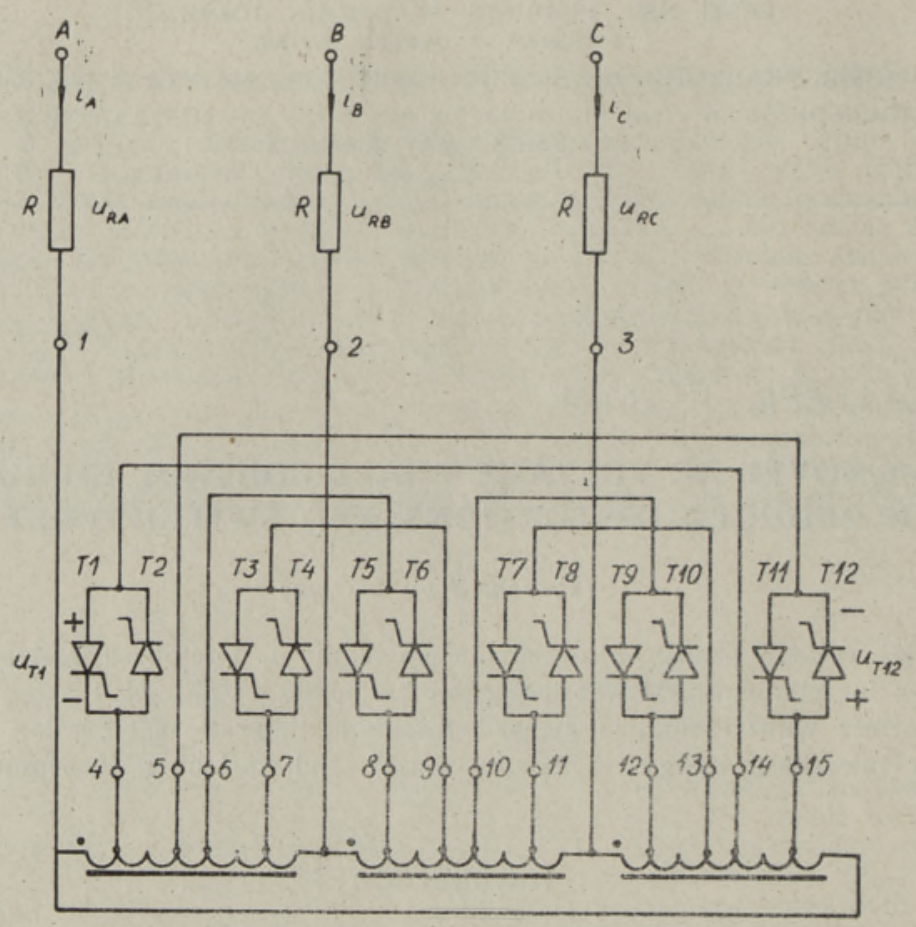

Fig. 1.

proper tap positions enables to choose the lower switch voltage independently from the supply voltage and to form an output voltage waveform containing harmonics with the order of $l=k p \pm 1$, where $k=1,2,3 \ldots$.

As in other phase-control circuits, the fundamental component of the load voltage can be varied by shifting the turn-on instants of the switches.

\section{Power circuit operation}

The following simplifying assumptions are made for the operation of the twelve-pulse phase-control circuit of Fig. 1.

1) The sinusoidal, three-phase source is ideal (sinusoidal supply voltages $u_{A}, u_{B}, u_{C}$ form a symmetrical three-phase system, $\left.u_{A}=U \cos \omega t\right)$.

2) The symmetrical load is purely resistive.

3) The autotransformer is ideal.

4) Bidirectional switches are realized by using ideal thyristors $\mathrm{T} 1 \ldots \mathrm{T} 12$ in an inverse-parallel connection.

Winding tapping is made so that, in the case of all thyristors turned off, the thyristor voltages $u_{\mathrm{T} 1} \ldots u_{\mathrm{T} 12}$ form a twelve-phase symmetrical system as shown in Figs $2, a$ and $2, b$. Below, the intervals of the circuit operation with only one of the thyristors T1 ...T12 turned on, will be considered. The parts of two phase windings from the taps to the common point of the windings are in parallel connection through the fired thvristor. As a result, the phase voltages are interdependent and the phase voltage ratio is determined by the turns ratio for the parts of phase windings in parallel connection. Therefore the choice of the above turns ratio influences the phase voltage ratio of the interphase autotransformer, consequently the load voltage ratio as well. The possibility to choose lower switch voltages independently from the supply voltage results from determining the phase voltage ratio of the autotransformer by turns ratio for the parts of two phase windings in parallel connection (see Fig. 2,a). 

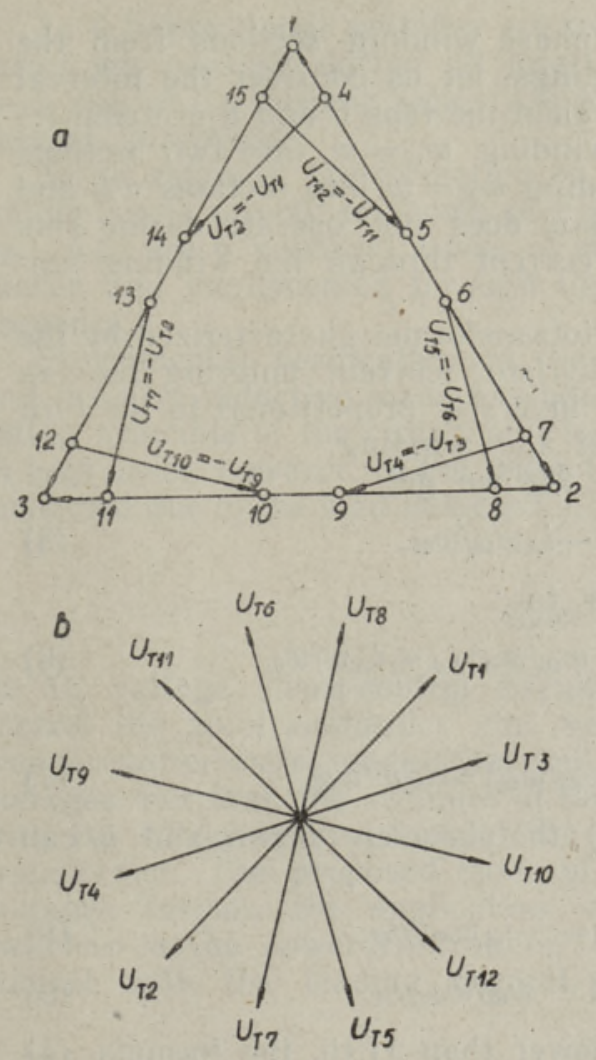

Fig. 2.

Power rating of the switches remains invariable because the reduction in switch voltages gives rise to the proportional increase in switch currents.

When varying phase voltage ratio both of the autotransformer and of the load with a certain sequence during each supply period, both the load voltage and current waveforms approximation to the sinewave will be possible. For that purpose an increase both in tap number and in the thyristors switching on frequence will also collaborate.

In ideal case $(p \rightarrow \infty)$ when all distortion harmonics have been eliminated and the phase currents $i_{A}$, $i_{B}, i_{C}$ are sinewaves, the following relation holds -

$$
\begin{gathered}
i_{A}: i_{B}: i_{C}=u_{R A}: u_{R B}: u_{R C}= \\
=\cos (\omega t+\varphi): \cos (\omega t+\varphi-2 \pi / 3): \cos (\omega t+\varphi+2 \pi / 3),
\end{gathered}
$$

where voltage across the resistive load in the phase $A$

$$
u_{R A}=U \cos \varphi \cos (\omega t+\varphi)
$$

and $\varphi$ is the displacement angle of load voltage.

In the above relation the interphase transformation ratios must be continuously varied. In static converters only a stepped variation of taps and current ratios is possible and therefore the absolute elimination of distortion harmonics cannot be achieved. In case of $p$-pulse operation mode, for instance a suitable stepped variation of phase current ratios enables to eliminate the distortion harmonics lower than $l=p-1$ in the load voltage and current waveforms.

For that; the following relation of phase currents is to be implemented -

$$
\begin{gathered}
i_{A}: i_{B}: i_{C}=\cos [\pi / p+(n-1) 2 \pi / p]: \\
: \cos [\pi / p-2 \pi / 3+(n-1) 2 \pi / p]: \cos [\pi / p+2 \pi / 3+(n-1) 2 \pi / p],
\end{gathered}
$$

where $n=1,2, \ldots p$. Each state is to last $1 / p$ interval of the supply period, and the state corresponding to $n=1$ is to be switched on at the moment $t=-\varphi / \omega$.

For the twelve-pulse case we get, accordingly

$$
\begin{gathered}
i_{A}: i_{B}: i_{C}=\cos \left[15^{\circ}+(n-1) 30^{\circ}\right]: \\
: \cos \left[-105^{\circ}+(n-1) 30^{\circ}\right]: \cos \left[135^{\circ}+(n-1) 30^{\circ}\right] .
\end{gathered}
$$


To determine the turns ratio of two phase winding sections from the taps to the common point of the windings, let us consider the interval with only the thyristor T5 conducting. Then the taps 6 and 8 are connected and the tap 6 divides the phase winding $w_{12}=w$ into two sections $w_{16}$ and $w_{62}$; the tap 8 divides the winding $w_{32}=w$ into sections $w_{38}$ and $w_{82}$, respectively. As the winding $w_{13}=w$ does not operate during this interval, the load current $i_{A}$ is the current through the winding section $w_{16}$.

Since we have assumed an ideal autotransformer characterized by the zero total magnetomotive force, the thyristor current entering the tap would be divided into two components inversely proportional to the turn number of the corresponding part of the winding.

For the winding sections $w_{16}$ and $w_{62}$ we get

$$
i_{62}=i_{16} w_{16} / w_{62}=-i_{A} w_{16} / w_{62},
$$

and the thyristor current $i_{T 5}$ equals to

$$
i_{T 5}=i_{16}-i_{62}=i_{16}+i_{26}=\left(1+w_{16} / w_{62}\right) i_{A}=i_{A} w / w_{62} .
$$

On the other hand,

$$
i_{T 5}=i_{83}+i_{82}=i_{83}\left(1+w_{83} / w_{82}\right)=i_{83} w / w_{82} .
$$

Taking into account the formulae $(5-7)$; the phase currents $i_{B}$ and $i_{C}$ can be written as follows

$$
\begin{gathered}
i_{C}=-i_{83}=-i_{T 5} w_{82} / w=-i_{A} w_{82} / w_{62}, \\
i_{B}=-i_{A}-i_{C}=-\left(1-w_{82} / w_{62}\right) i_{A} .
\end{gathered}
$$

For eliminating distortion harmonics lower than 11-th, the formula (4) must be satisfied. For the interval considered (T5 being fired) $n=12$, and the relationship (4) takes the form

$i_{A}: i_{B}: i_{C}=1:(-0,732):(-0,268)=\cos 15^{\circ}:\left(-\cos 45^{\circ}\right):\left(-\cos 75^{\circ}\right)$,

which corresponds to the turns ratio

$$
w_{62}: w_{82}=1: 0,268=\cos 15^{\circ}: \cos 75^{\circ} .
$$

It must be pointed out that the relation (10) holds for all $n=1, \ldots p$, only the particular phases with the maximum, intermediate, or minimum current level change from one state to another, respectively. The supply period is divided into 12 equal intervals each of which corresponds to the stepped variation of phase current ratio. The switching sequence of the thyristors is shown in Fig. 3.

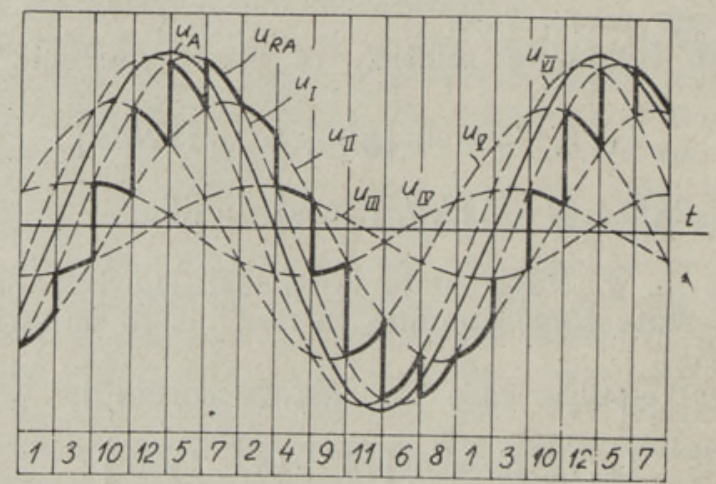

Fig. 3. 
As 6 bidirectional switches are used in the circuit, 6 different current ratios are possible during 12 intervals, i.e. for the states with $n$ and $n+6$ the phase current ratios are exactly the same with the opposite current directions.

As an example; the formation of load voltage waveform for the controlling angle $\alpha=30^{\circ}$ is shown in Fig. 3. (In ideal case $\alpha=\varphi$ ). Voltages $u_{\mathrm{I}} \ldots u_{\mathrm{VI}}$ are 6 potential levels of the load voltage $u_{R A}$, which can be chosen and implemented through turning on the thyristors in the given sequence.

Experimental verification of the proposed circuit both for resistive and resistive-inductive loads has been carried out in the laboratory. Operating principle of the circuit and load voltage waveforms were identical in both cases, however, in the latter the load current waveform was better smoothed due to the load inductivity.

\section{Conclusions}

In $\mathrm{AC}$ voltage phase-contral circuits with interphase energy exchange control the autotransformer can be employed both for the interphase transformation-ratio modulation and for matching of supply and switch voltages. For that, the switches of the circuit should be connected directly with the corresponding taps of the neighbouring windings of the autotransformer. The proposed mode of matching of the supply and switch voltages favours the application of transistors as fully-controllable switches in the power controllers, facilitating, at the same time, the control with the leading current.

\section{REFERENCES}

1. Оявеэр M., Саккос T., Сарв B. Вентильно-индуктивные цепи непрерывного амплитудного регулирования переменного напряжения. Таллин, «Валгус», 1978.

2. Сарв В. В. В кн.: Источники электропитания со специальными характеристиками. Киев, «Наукова думка», 1979, $106-113$.

3. Сарв В. В. В кн.: Проблемы преобразовательной техники, ч. 3. Киев, Изд. АН УкрССР, 1979, 10-13.

4. Сарв В. В. В кн.: Электромагнитное совмещение силовых полупроводниковых преобразователей. Таллин, Изд. АН ЭССР, 1981, 103-109.

5. Sarv. V. In: 4th Power Electronics Conference, Budapest 81. III Static Energy Converters. Budapest, OMKDK - Technoinform, 1981, 117-127.

6. Sarv, V. ENSV TA Toim., Füüs. Matem., 32, № 1, $70-77$ (1983).

7. Сарв В. В., Ранне И.. Э., Сооярв Ю. Э., Суй Р. Х. Авт. свид. СССР № 851361. Бюл. изобр. № 28 (1981).

8. Сарв В. В., Ранне И. Э., Сооярв Ю. Э. Авт. свид. СССР № 873223 . Бюл. изобр. № 38 (1981).

9. Ранне И. Э., Сарв В. В., Сооярв Ю. Э. Авт. свид. СССР № 913529. Бюл. изобр. № 10 (1982).

10. Сарв В. В., Ранне И. Э., Саккос Т. Ю., Сооярв Ю. Э. Авт. свид. СССР № 941964. Бюл. изобр. № 25 (1982).

11. Сарв В. В., Ранне И. Э., Саккос Т. Ю., Сооярв Ю. Э. Авт. свид. СССР № 951256. Бюл. изобр. № 30 (1982).

12. Ojaveer, M. ENSV TA Toim., Füüs. Matem., 30, № 3, 260-267 (1981).

Academy of Sciences of the Estonian SSR, Institute of Thermophysics and Electrophysics

Received April 28, 1983 


\title{
VAHELDUVPINGE VÄHEMOONUTAVA FAASIREGULEERIMISE VÄHENDATUD LOLITIPINGETEGA SKEEM
}

On tutvustatud ja analüüsitud uut vahelduvpingeregulaatorit, kus madalamate moonutusharmooniliste kõrvaldamiseks kasutatakse muudetava ülekandeteguriga faasidevahelist autotrafot, mis võimaldab otstarbekalt juhtida faasidevahelist energiavahetust ja vähendada lülitite pinget.

Maйре ОЯВЕЭР, В. САРВ

\section{НОВАЯ СХЕМА ДЛЯ МАЛОИСКАЖЕННОГО ФАЗОВОГО РЕГУЛИРОВАНИЯ ПЕРЕМЕННОГО НАПРЯЖЕНИЯ С УМЕНЬШЕННЫМИ НАПРЯЖЕНИЯМИ НА КЛЮЧАХ}

\begin{abstract}
Предлагается новая перспективная вентильно-индуктивная схема для малонскаженного фазового регулирования трехфазного переменного напряжения; в которой уменьшение искажающих гармоник достигается в результате подходящего межфазного энергообмена. Основными элементами схемы являются межфазный автотрансформатор с соединенными в треугольник фазными обмотками, имеющими отводы, и ключевой коммутатор для периодического переключения коэффициентов трансформации. Число необходимых однонаправленных ключей равно пульсности схемы. Преимуществом предлагаемой схемы является возможность использования межфазного автотрансформатора не только в целях регулирования и сглаживания тока нагрузки, а также в целях согласования номинальных напряжений ключей и питания. Это способствует увеличению надежности и упрощению устройства.
\end{abstract}

